\title{
Monte Carlo Analysis of the Effects of a Blanket-Shield Penetration on the Performance of a Tokamak Fusion Reactor
}

\author{
R. T. Santoro \\ J. S. Tang \\ R. G. Alsmiller, Jr. \\ J. M. Barnes
}

\section{OAK RIDGE NATIONAL LABORATORY}

OPERATED BY UNION (ARBIDE CORPORATION FOR THE ENERGY RESEARCH ANI) IIHVHLUPMENI AUMINISTRATION 


\section{DISCLAIMER}

This report was prepared as an account of work sponsored by an agency of the United States Government. Neither the United States Government nor any agency Thereof, nor any of their employees, makes any warranty, express or implied, or assumes any legal liability or responsibility for the accuracy, completeness, or usefulness of any information, apparatus, product, or process disclosed, or represents that its use would not infringe privately owned rights. Reference herein to any specific commercial product, process, or service by trade name, trademark, manufacturer, or otherwise does not necessarily constitute or imply its endorsement, recommendation, or favoring by the United States Government or any agency thereof. The views and opinions of authors expressed herein do not necessarily state or reflect those of the United States Government or any agency thereof. 


\section{DISCLAIMER}

Portions of this document may be illegible in electronic image products. Images are produced from the best available original document. 


\section{Printed in the United States of America. Available from National Technical Information Service \\ U.S. Department of Commerce \\ 5285 Port Royal Road, Springfield, Virginia 22161 \\ Price: Printed Copy $\$ 4.00$; Microfiche $\$ 3.00$}

This report was prepared as an account of work sponsored by the United States Government. Neither the United States nor the Energy Research and Development Administration/United States Nuclear Regulatory Commission, nor any of their employees, nor any of their contractors, subcontractors, or their employees, makes any warranty, express or implied, or assumes any legal liability or responsibility for the accuracy, completeness or usefulness of any information, apparatus, product or process disclosed, or represents that its use would not infringe privately owned rights. 
Contract No. W-7405-eng-26

Neutron Physics Division

\section{MONTE CARLO ANALYSIS OF THE EFFECTS OF A BLANKET-SHIELD PENETRATION ON THE PERFORMANCE OF A TOKAMAK FUSION REACTOR *}

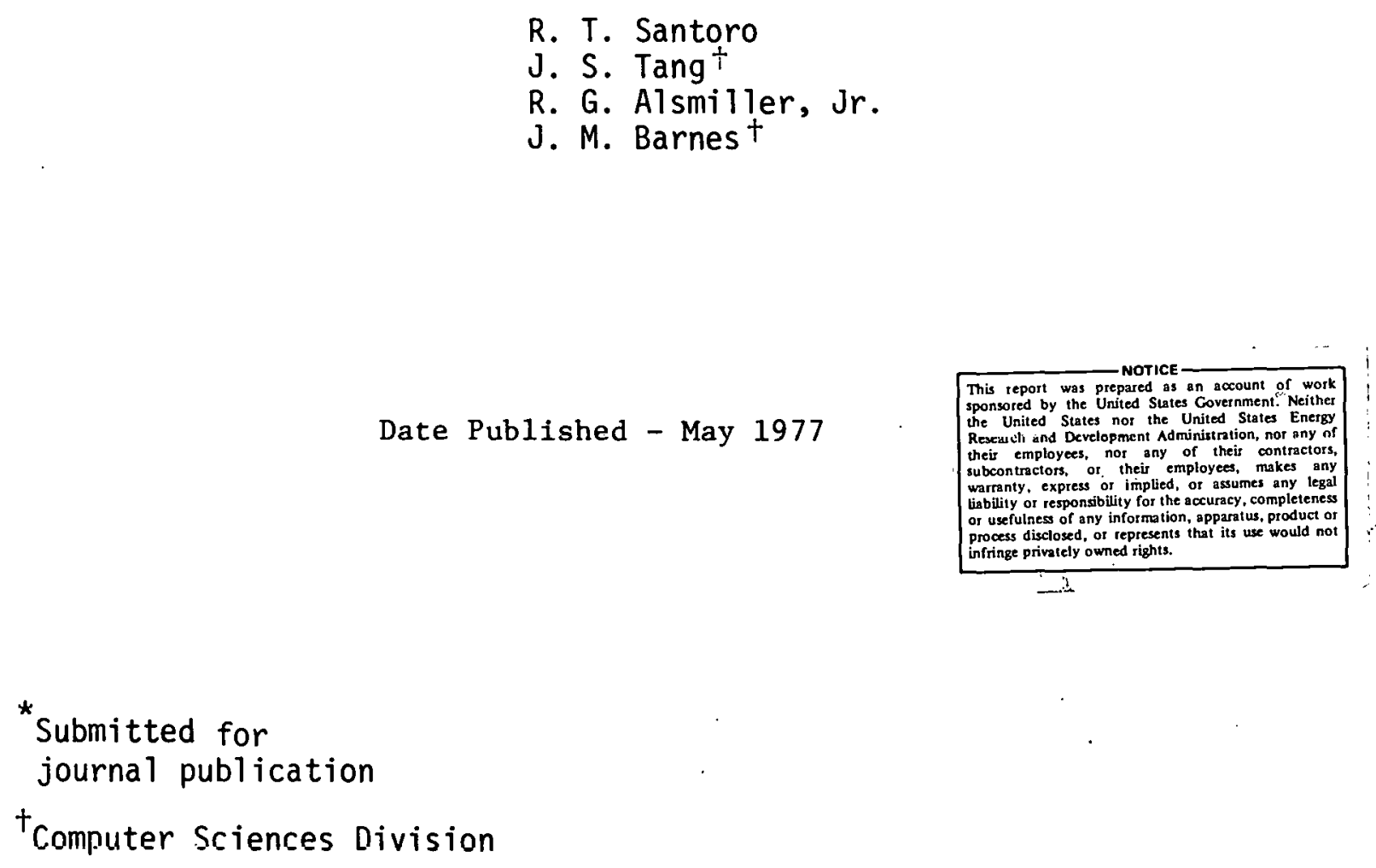

NOTICE This document contains information of a preliminary nature. It is subject to revision or correction and therefore does not represent a final report.

OAK RIDGE NATIONAL LABORATORY

Oak Ridge, Tennessee 37830 operated by

UNION CARBIDE CORPORATION

for the

ENERGY RESEARCH AND DEVELOPMENT ADMINISTRATION

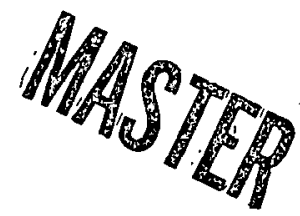

DISTRIBUTION OF THIS DOCUMENT IS UNLIMITEA 
THIS PAGE

\section{WAS INTENTIONALLY \\ LEFT BLANK}


Adjoint Monte Carlo calculations have been carried out using the three-dimensional radiation transport code, MORSE, to estimate the nuclear heating and radiation damage in the toroidal field (TF) coils adjacent to a $28 \times 68 \mathrm{~cm}^{2}$ rectangular neutral beam injector duct that passes through the blanket and shield of a D-T burning Tokamak reactor. The plasma region, blanket, shield, and TF coils were represented in cylindrical geometry using the same dimensions and compositions as those of the Experimental Power Reactor. The radiation transport was accomplished using coupled 35-group neutron, 21-group gamma-ray cross sections obtained by collapsing the DLC-37 cross-section library. Nuclear heating and radiation damage rates were estimated using the latest available nuclear response functions. The presence of the neutral beam injector duct leads to increases in the nuclear heating rates in the TF coils ranging from a factor of 3 to a factor of 196 depending on the location. Increases in the radiation damage also result in the TF coils. The atomic displacement rates increase from factors of 2 to 138 and the hydrogen and helium gas production rates increase from factors of 11 to 7600 and from 15 to 9700 , respectively. 


\section{Introduction}

Monte Carlo methods have been used to estimate the effects on the performance of a representative D-T burning Tokamak fusion reactor resulting from the radiation that streams through a neutral beam injector penetration in the blanket-shield assembly. The number of penetrations, as well as the size of some of these penetrations, will be appreciable, so the ability of the blanket-shield assembly to attenuate the plasma neutron and secondary-gamma radiation will be reduced. The radiation through neutral beam injector ducts, vacuum ports, diagnostic ports, etc. may lead to intolerable nuclear heating and radiation damage in vital reactor components, particularly in the cryogenic toroidal field (TF) coils that surround the reactor. The effects of neutron streaming through neutral beam injection ports on the performance of a fusion reactor have been studied by Ide et al., ${ }^{1}$ using two-dimensional radiation transport methods. Abdou et al., ${ }^{2}$ have calculated neutron flux distributions in the vicinity of shielded penetrations having various dimensions and angles of incidence to the plasma axis using three-dimensional methods.

This paper summarizes the results of calculations using adjoint Monte Carlo methods that were carried out to estimate the nuclear heating and radiation damage at selected locations in the TF coils adjacent to a rectangular neutral beam injector duct that passes through the blanket and shield. The calculations were performed using the three-dimensional radiation transport code MORSE ${ }^{3}$. The nuclear responses obtained using this code were compared with similar data obtained previous $7 y^{4}, 5$ using the one-dimensional discrete ordinates code ANISN6. The nuclear heating 
and radiation damage obtained using one-dimensional methods are for the reactor configuration without penetrations.

The calculational model and methods and the nuclear data used in the calculations are discussed in Sec. II. The results are presented and discussed in Sec. III.

\section{Details of the Calculations}

The model used to represent the reactor and the neutral beam injector penetration in the calculations is shown in Fig. 1. The toroidal-shaped plasma region, blanket, and shield are represented by coaxial rightcircular cylinders $1415 \mathrm{~cm}$ long and having radial dimensions corresponding to those in the Experimental Power Reactor ${ }^{4}, 5$. The composition of the blanket was taken to be that of the tritium breeding module proposed for use in the EPR. The dimensions and compositions of the components are given in Table 1. The TF coils were treated as cylindrical segments having approximately the same radial and lateral dimensions of the TF coils that surround the assembly. The coil spacing along the cylinder corresponds to the spacing of the coils about the outer toroidal surface. For the purposes of calculation, the conductor material in the coil was a homogenized composition consisting of $52.5 \mathrm{v} / \mathrm{o} \mathrm{Al}, 14.0 \mathrm{v} / \mathrm{o} \mathrm{Cu}, 4.9 \mathrm{v} / \mathrm{o}$ $\mathrm{Nb}_{3} \mathrm{Sn}, 0.6 \mathrm{v} / 0 \mathrm{Sn}$, and $28 \mathrm{v} / \mathrm{o} \mathrm{He}$.

The neutral beam injector duct passes through the blanket-shield assembly between two TF coils at a grazing angle of $24^{\circ}$ with the axis of cylindrical symmetry. The duct has a cross-sectional area of $28 \times 68 \mathrm{~cm}^{2}$ and a SS-316 wall thickness of $1 \mathrm{~cm}$. Modelling the injector in this manner simulates tangential neutral beam injection. Also, the 


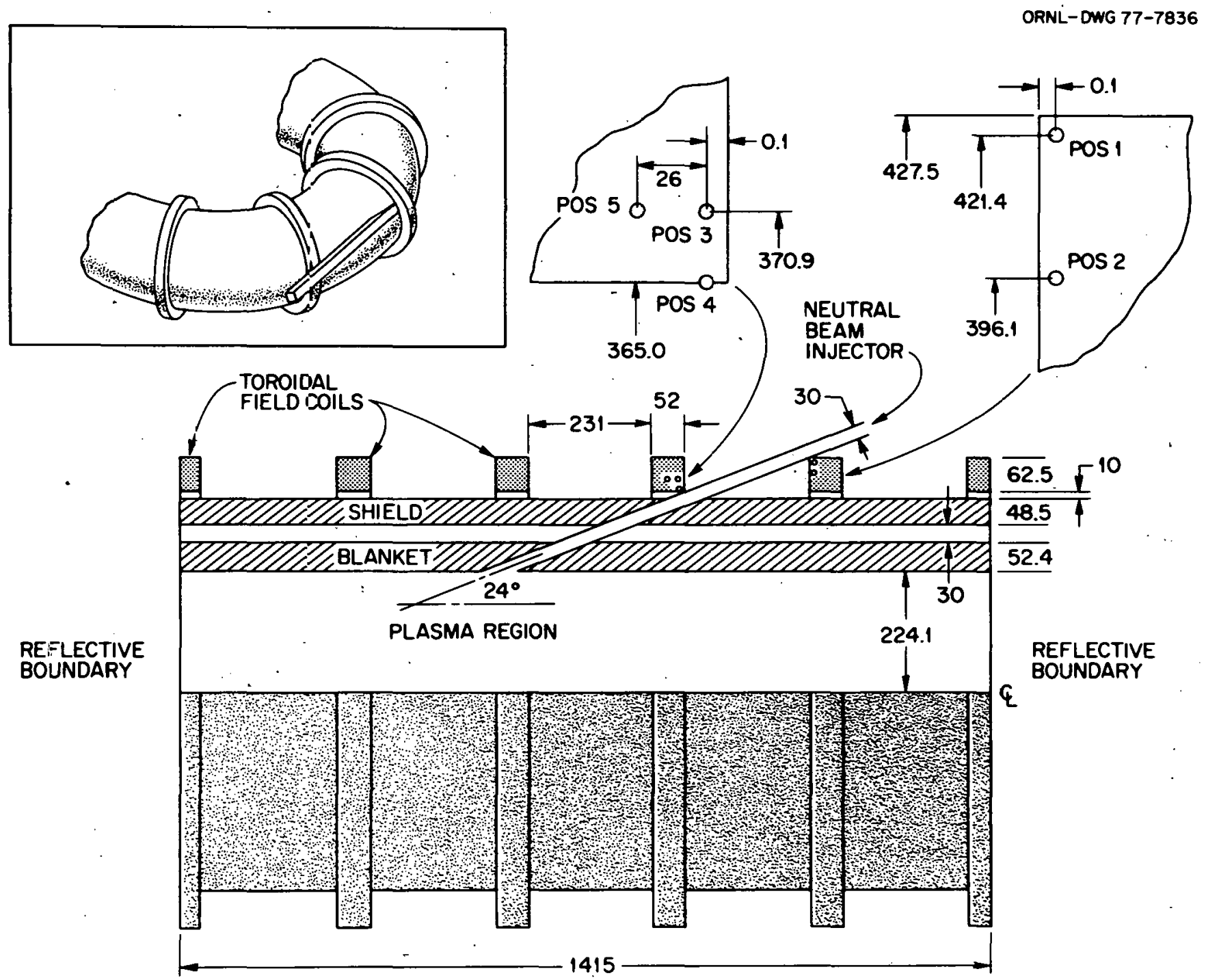

NOTE: DIMENSIONS IN cm

Fig. 1. The Representation of the Tokamak Reactor and Injector Duct Used in the Monte Carlo Calculations. 
TABLE I. DIMENSIONS AND COMPOSITIONS OF THE REACTOR COMPONENTS

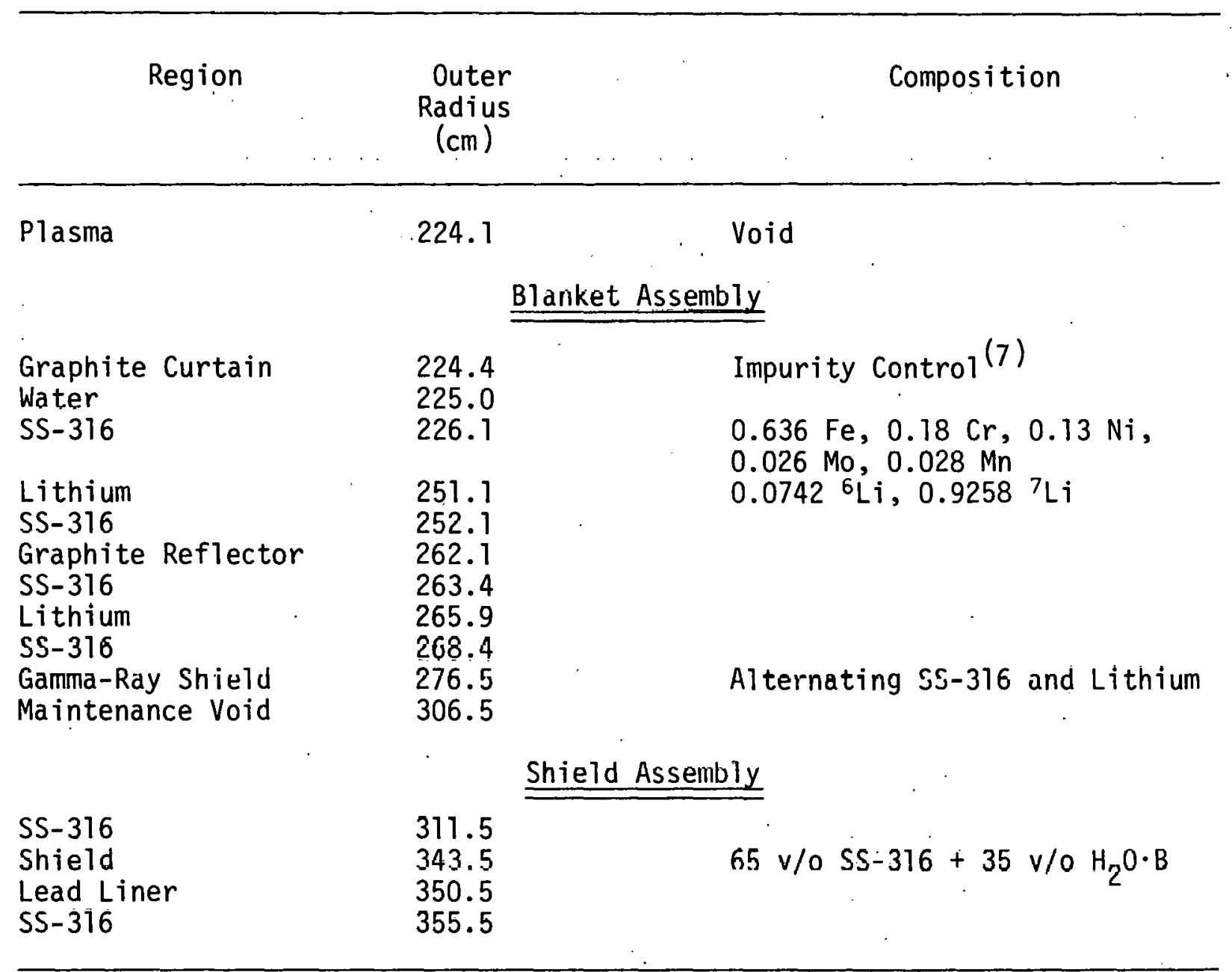

(7) Kulcinski, G. L. El al..,. "A Method to Reduce the Effects of Plasma Contamination and First-Wa11 Erosion in Fusion Reactors," UWFDM-108, University of Wisconsin (1974). 
angle of injection was chosen so that little or no additional shielding could be placed adjacent to the TF coils. The nuclear heating rates and radiation damage at five locations in the TF coils adjacent to the injector were estimated using adjoint Monte Carlo radiation transport methods. Generally, the nuclear response is determined from the integral over all phase space $\bar{p}$ of the particle flux distribution, $\Phi(\bar{p})$, and the macroscopic response function, $\Sigma(E, \bar{r})$ given by

$$
R=\int_{\substack{\text { all } \\ \text { space }}} \Phi(\bar{p}) \Sigma(E, \bar{r}) d \bar{p}
$$

where $d \bar{p}=d \bar{r} d E d \bar{\Omega}$. In this equation, the particle flux distribution is determined from the solution of the forward transport equation with a particle source term $S(\bar{p})$. That is

$$
\hat{H} \Phi(\bar{p})=S(\bar{p})
$$

where $\hat{H}$ is the forward Boltzmann operator. However, for this problem the large source volume, the locations of the detectors in the TF coils relative to the mouth of the duct, and the large attenuation factor $\left(\sim 10^{5}\right)$ of the blanket and shield make forward Monte Carlo calculations problematic. ${ }^{2}$ Strong source position and angular biasing are necessary and preliminary forward calculations were performed, but the results were unsatisfactory from the point of view of running time and statistical uncertainty. Based on these considerations, the adjoint Monte Carlo approach was used. In adjoint Monte Carlo calculations, the nuclear response is obtained from the integral

$$
R=\int_{\substack{\text { all phase } \\ \text { space }}} \Phi^{*}(\bar{p}) s(\bar{p}) d \bar{p}
$$


where $\Phi^{*}(\bar{p})$ is the adjoint flux which is the solution of the adjoint Boltzmann transport equation using the nuclear response function $\Sigma(E, \bar{r})$, as the source term. That is

$$
\hat{H}^{\star} \Phi^{*}(\bar{p})=\Sigma(E, \bar{r})
$$

where $\hat{H}^{\star}$ is the adjoint Boltzmann operator. A detailed derivation establishing the relationships between these equations and the indentification of $\Sigma(E, \bar{r})$ as the adjoint source term are given by Hansen and Sandmeier ${ }^{8}$. In general, the disadvantages of using the adjoint radiation transport method is that a separate transport calculation must be carried out for each nuclear response and for each detector site. In multigroup adjoint Monte Carlo calculations, however, it is possible, as shown below, to obtain any number of nuclear responses at a given detector from one adjoint calculation, but a separate calculation is still required for each detector site. In multigroup adjoint Monte Carlo calculations, $\Sigma_{j}(\bar{r})$ is the adjoint source in energy group $j$ and

$$
\sum_{j=1}^{n} \sum_{j}(\bar{r})=\Sigma(E, \bar{r}) \text {. }
$$

Since $\hat{H}^{*}$ is a linear operator and

$$
\sum_{j=1}^{n} \Phi^{*} j(p)=\Phi^{*}(p),
$$

Eq. (4) may be broken up into $n$ equations

$$
\begin{gathered}
\hat{H}^{\star} \Phi^{\star 1}(\bar{p})=\Sigma_{1}(\bar{r}) \\
\hat{H}^{*}{ }^{\star 2}(\bar{p})=\Sigma_{2}(\bar{r}) \\
\cdot \\
\hat{H}^{*}{ }^{*} n(\bar{p})=: \Sigma_{n}(\bar{r})
\end{gathered}
$$


that are evaluated separately for each $\Sigma_{j}(\bar{r})$. The corresponding nuclear response for each of the above equations is

$$
\begin{aligned}
R_{1} & =\int \Phi^{* 1}(\bar{p}) S(\bar{p}) d \bar{p} \\
R_{2} & =\int \Phi^{* 2}(\bar{p}) S(\bar{p}) d \bar{p} \\
\cdot & \cdot \\
R_{n} & =\int \Phi^{*} \cdot(\bar{p}) S(\bar{p}) d \bar{p}
\end{aligned}
$$

and the total nuclear response is

$$
R=\sum_{j=1}^{n} R_{j}
$$

For a new response function $\Sigma^{\prime}(E, \bar{r})=\sum_{j=1}^{n} \Sigma_{j}^{\prime}(\bar{r})$, the total nuclear response $R^{\prime}$ can be obtained from

$$
R^{\prime}=\sum_{j=1}^{n} R_{j}^{\prime}
$$

where

$$
\cdot R_{j}^{\prime}=R_{j}\left[\frac{\sum_{j}^{\prime}(\bar{r})}{\sum_{j}(\bar{r})}\right]
$$

To obtain a nuclear response due to a different response function $\Sigma_{j}^{\prime}(\bar{r})$, one applies Eq. (9) every time a contribution to $R_{j}$ is made.

To facilitate the calculations, adjoint source angular biasing was used to direct more particles toward the plasma region through the duct rather than transporting large numbers of particles through regions of the blanket and shield away from the penetration. Furthermore, path length stretching, nonabsorption weighting, Russian roulette, and splitting were employed. 
Two estimatorswere used in the calculations. They are the nextflight track length estimator and the true track length estimator. For the true track length estimation, the tracks of adjoint particles inside the plasma volume were scored. For the next-flight track length estimation, adjoint particles that are directed toward the plasma were scored for each collision.

The radiation trasnport was accomplished using coupled 35 energy group neutron-21 energy group gamma-ray cross sections obtained by collapsing the $100 n-21$ y DLC-37 cross-section 1 ibrary 9,10 . The nuclear heating rates were obtained using fluence-to-kerma response functions generated by $M A C K^{11}$ and SMUG ${ }^{2}$ and radiation damage was estimated using atomic displacement and gas production cross sections generated by the code RECOIL 13 .

\section{Discussion of Results}

The calculated nuclear heating rates at the various locations in the TF coils adjacent to the neutral beam injector duct are summarized in Table II. The detector position numbers correspond to those as shown in the inset in Fig. 1. The neutron, gamma-ray, and total (neutron plus gamma-ray) heating rates using both the next-flight and true track length estimation techniques are given at each detector location. In all cases, the kerma factor for the TF coil conductor was used as the source term in the adjoint calculations. The fractional values given below each entry are the calculated standard deviations for each response. The entries labeled "MORSE/ANISN RATIO" indicate the effect of the penetration on each response. The ANISN6 results are for the reactor configuration without a penetration. All of the results have been normalized to a · 
TABLE II. NUCLEAR HEATING RATES AT VARIOUS LOCATIONS IN THE TOROIDAL FIELD COILS

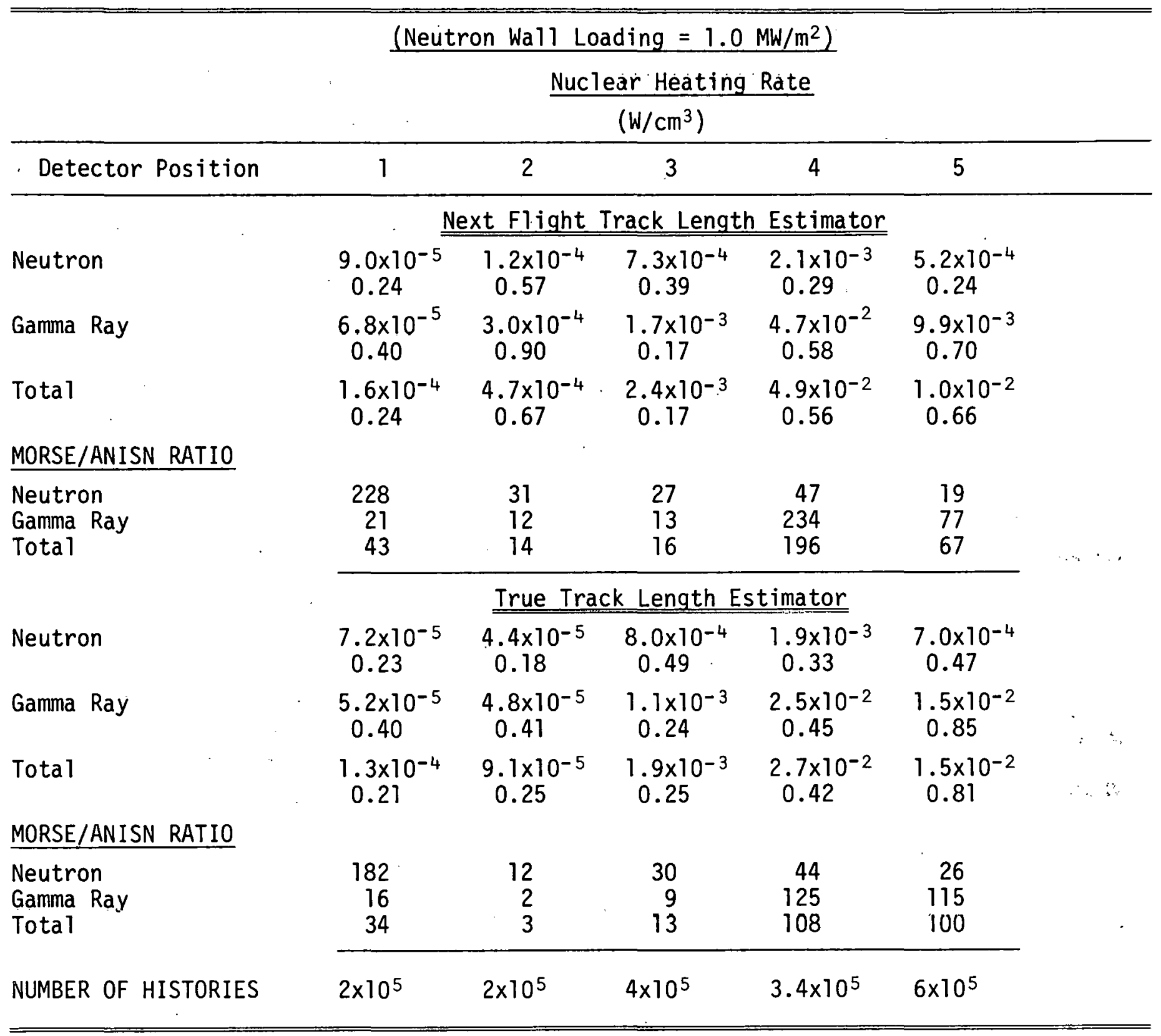


neutron-wall loading of $1 \mathrm{MW} / \mathrm{m}^{2}\left(4.43 \times 10^{13} \mathrm{n} / \mathrm{cm}^{2} / \mathrm{sec}\right)$ at continuous reactor operation.

The inclusion of the neutral beam injector leads to increases in the nuclear heating rates in the coils ranging from a factor of 3 to a factor of 196 depending on the location in the coils relative to the duct. The heating rates at each detector position obtained using both track-length estimators agree with the statistical deviations albeit, in some cases, these uncertainties are quite large.

The neutron heating rate at detector position 1 is due, in large part, to neutrons streaming through the duct as evidenced by the value ( $\sim 200$ ) in the MORSE/ANISN RATIO. This portion of the coil has a direct view of the plasma through the duct. The nuclear heating rates at detector position 2 are comparable to the values at location 1 , but the effects of the injector are smaller. There is more shielding material between the plasma region and this portion of the coil. The uncertainties in the gamma-ray heating rates at detector positions 1 and 2 are large compared to the uncertainties in the neutron heating rates.

Detector positions 3 and 4 each 7 ie along the same radius from the plasma but are separated by $6 \mathrm{~cm}$. The differences in the neutron and gamma-ray heating rates at these locations are due to shielding of detector position 3 by the material in the coil. The gamma-ray heating rates at detector position 4 are accompanied by large uncertainties so the increase in the heating rate relative to the fully shielded case may be overestimated. The gamma-ray heating at position 4 may be attributed to photons produced by energetic neutron reactions near the outer layers of the shield. These photons are attenuated in the coil resulting in lower heating rates at location 3 . 
Further calculations are required to reduce the statistical uncertainties in some of the data in Table I. The uncertainties in the gamma-ray heating at detector position 5 are quite large and the effects of the penetration on the total heating rates at this location may be overestimated relative to the fully shielded case. This portion of the coil is more shielded from the plasma than detector positions 3 and 4 and the radiation transport is more difficult because of the larger amount of material between the injector opening at the plasma and the detector.

In all cases, however, the presence of the penetration results in increases in the nuclear heating rates in the TF coils of sufficient magnitude to influence the cryogenics of the TF coils.

The radiation damage induced at the various locations and in the different materials in the TF coils due to the presence of the injector duct is summarized in Tables III, IV, and V. The radiation damage is compared in terms of the atomic displacement rate in displacements per atom per year in Table III, and in terms of the hydrogen and helium gas production rates in atom parts per million per year in Tables IV and $V$, respectively. The atomic displacement rates were calculated using effective displacement energies of $40 \mathrm{eV}$ for SS-316, $60 \mathrm{eV}$ for $\mathrm{Nb}$, $30 \mathrm{eV}$ for $\mathrm{Cu}$, and $25 \mathrm{eV}$ for $\mathrm{Al}$. All of the important charged particleproducing reactions were taken into account in the calculation of the gas production rates. The gas production data were obtained using Eq. (9), but no statistical uncertainties were calculated. The uncertainties associated with these results are not expected to be significantly different than those calculated for the atomic displacement rates for the same materials and estimators given in Table III. 
TABLE III. ATOMIC DISPLACEMENT RATES AT VARIOUS LOCATIONS IN THE TOROIDAL FIELD COILS

(Neutron Wall Loading $=1.0 \mathrm{MW} / \mathrm{m}^{2}$ )

Atomic Displacement Rate ${ }^{(a)}$

(DPA per Year) ${ }^{(b)}$

\begin{tabular}{|c|c|c|c|c|c|}
\hline Detector Position & 1 & 2 & 3 & 4 & 5 \\
\hline & \multicolumn{5}{|c|}{ Next Flight Track Length Estimator } \\
\hline SS-316 & $\begin{array}{c}5.0 \times 10^{-4} \\
0.39\end{array}$ & $\begin{array}{c}4.8 \times 10^{-4} \\
0.53\end{array}$ & $\begin{array}{c}7.9 \times 10^{-3} \\
0.51\end{array}$ & $\begin{array}{l}1.0 \times 10^{-2} \\
0.28\end{array}$ & $\begin{array}{c}5.5 \times 10^{-3} \\
0.29\end{array}$ \\
\hline $\mathrm{Nb}$ & $\begin{array}{c}4.4 \times 10^{-4} \\
0.39\end{array}$ & $\begin{array}{c}4.3 \times 10^{-4} \\
0.52\end{array}$ & $\begin{array}{c}9.2 \times 10^{-3} \\
0.59\end{array}$ & $\begin{array}{l}9.6 \times 10^{-3} \\
0.26\end{array}$ & $\begin{array}{c}7.6 \times 10^{-3} \\
0.31\end{array}$ \\
\hline $\mathrm{Cu}$ & $\begin{array}{c}6.2 \times 10^{-4} \\
0.40\end{array}$ & $\begin{array}{c}6.0 \times 10^{-4} \\
0.53\end{array}$ & $\begin{array}{c}1.1 \times 10^{-2} \\
0.59\end{array}$ & $\begin{array}{c}1.3 \times 10^{-2} \\
0.28\end{array}$ & $\begin{array}{c}6.3 \times 10^{-3} \\
0.27\end{array}$ \\
\hline A1 & $\begin{array}{c}5.2 \times 10^{-4} \\
0.39\end{array}$ & $\begin{array}{c}4.6 \times 10^{-4} \\
0.49\end{array}$ & $\begin{array}{c}1.8 \times 10^{-2} \\
0.64\end{array}$ & $\begin{array}{c}1.1 \times 10^{-2} \\
0.24\end{array}$ & $\begin{array}{c}8.9 \times 10^{-3} \\
0.30\end{array}$ \\
\hline \multicolumn{6}{|l|}{ MÖRSE/ÄNISN RATIO } \\
\hline \multirow[t]{2}{*}{$\begin{array}{l}\mathrm{SS}-316 \\
\mathrm{Nb} \\
\mathrm{Cu} \\
\mathrm{Al}\end{array}$} & $\begin{array}{r}138 \\
97 \\
89 \\
51\end{array}$ & $\begin{array}{r}13 \\
9 \\
10 \\
5\end{array}$ & $\begin{array}{l}27 \\
24 \\
27 \\
29\end{array}$ & $\begin{array}{l}22 \\
16 \\
20 \\
20\end{array}$ & $\begin{array}{l}19 \\
20 \\
15 \\
14\end{array}$ \\
\hline & \multicolumn{5}{|c|}{ True Track Length Estimator } \\
\hline SS-316. & $\begin{array}{c}3.4 \times 10^{-4} \\
0.24\end{array}$ & $\begin{array}{c}1.9 \times 10^{-4} \\
0.17\end{array}$ & $\begin{array}{c}7.4 \times 10^{-3} \\
0.60\end{array}$ & $\begin{array}{c}8.2 \times 10^{-3} \\
0.29\end{array}$ & $\begin{array}{c}1.0 \times 10^{-2} \\
0.55\end{array}$ \\
\hline $\mathrm{Nb}$ & $\begin{array}{c}3.0 \times 10^{-4} \\
0.24\end{array}$ & $\begin{array}{c}1.7 \times 10^{-4} \\
0.17\end{array}$ & $\begin{array}{c}9.2 \times 10^{-3} \\
0.67\end{array}$ & $\begin{array}{c}8.6 \times 10^{-3} \\
0.27\end{array}$ & $\begin{array}{c}1.3 \times 10^{-2} \\
0.49\end{array}$ \\
\hline $\mathrm{Cu}$ & $\begin{array}{c}4.2 \times 10^{-4} \\
0.24\end{array}$ & $\begin{array}{c}2.4 \times 10^{-4} \\
0.17\end{array}$ & $\begin{array}{c}1.1 \times 10^{-2} \\
0.64\end{array}$ & $\begin{array}{c}1.2 \times 10^{-2} \\
0.29\end{array}$ & $\begin{array}{c}1.3 \times 10^{-2} \\
0.58\end{array}$ \\
\hline Al & $\begin{array}{c}3.7 \times 10^{-4} \\
0.34\end{array}$ & $\begin{array}{c}1.9 \times 10^{-4} \\
0.17\end{array}$ & $\begin{array}{c}1.9 \times 10^{-2} \\
0.70\end{array}$ & $\begin{array}{c}1.1 \times 10^{-2} \\
0.25\end{array}$ & $\begin{array}{c}1.9 \times 10^{-2} \\
0.60\end{array}$ \\
\hline \multicolumn{6}{|l|}{ MORSE/ANISN RATIO } \\
\hline $\begin{array}{l}\mathrm{SS}-316 \\
\mathrm{Nb} \\
\mathrm{Cu} \\
\mathrm{Al}\end{array}$ & $\begin{array}{l}95 \\
66 \\
60 \\
36\end{array}$ & $\begin{array}{l}5 \\
3 \\
4 \\
2\end{array}$ & $\begin{array}{l}26 \\
23 \\
26 \\
30\end{array}$ & $\begin{array}{l}20 \\
15 \\
18 \\
26\end{array}$ & $\begin{array}{l}35 \\
32 \\
32 \\
31\end{array}$ \\
\hline
\end{tabular}

(a) Based on effective displacement energies of $40 \mathrm{eV}$ for SS-316, $60 \mathrm{eV}$ for $\mathrm{Nb}$, $30 \mathrm{eV}$ for $\mathrm{Cu}$, and $25 \mathrm{eV}$ for $\mathrm{Al}$.

(b) Displacements per atom per year. 
TABLE IV. HYDROGEN GAS PRODUCTION RATES AT VARIOUS LOCATIONS IN THE TOROIDAL FIELD COILS

\begin{tabular}{|c|c|c|c|c|c|c|}
\hline & (Neut & on Wall Lo & ding $=1.0$ & $\left.\mathrm{MW} / \mathrm{m}^{2}\right)$ & & \\
\hline & & $\frac{\text { Hydro }}{\text { (AP }}$ & $\frac{\text { en Gas Pro }}{\text { M Per Year }}$ & $\frac{\text { uction }}{\text { (a) }}$ & & \\
\hline Detector Position & 1 & 2 & 3 & 4 & 5 & \\
\hline & & lext Flight & Track Lens & h Estimato & & \\
\hline SS-316 & $2.3 \times 10^{-2}$ & $2.4 \times 10^{-2}$ & $8.2 \times 10^{-2}$ & $4.5 \times 10^{-1}$ & $8.9 \times 10^{-2}$ & \\
\hline $\mathrm{Nb}$ & $4.6 \times 10^{-3}$ & $5.5 \times 10^{-3}$ & $1.2 \times 10^{-2}$ & $9.9 \times 10^{-2}$ & $1.6 \times 10^{-2}$ & \\
\hline $\mathrm{Cu}$ & $2.0 \times 10^{-2}$ & $2.7 \times 10^{-2}$ & $9.3 \times 10^{-2}$ & $4.6 \times 10^{-1}$ & $1.2 \times 10^{-1}$ & \\
\hline Al & $1.3 \times 10^{-2}$ & $1.1 \times 10^{-2}$ & $3.7 \times 10^{-2}$ & $2.3 \times 10^{-1}$ & $3.6 \times 10^{-2}$ & \\
\hline MORSE/ANISN RATIO & & & & & & \\
\hline $\begin{array}{l}\text { SS-316 } \\
\mathrm{Nb} \\
\mathrm{Cu} \\
\mathrm{AI}\end{array}$ & $\begin{array}{l}7455 \\
7666 \\
5000 \\
8666\end{array}$ & $\begin{array}{l}322 \\
275 \\
270 \\
261\end{array}$ & $\begin{array}{l}41 \\
34 \\
47 \\
39\end{array}$ & $\begin{array}{l}103 \\
152 \\
107 \\
127\end{array}$ & $\begin{array}{l}20 \\
24 \\
30 \\
20\end{array}$ & $\vdots$ \\
\hline & & True Tr & ck Length & stimator & & \\
\hline SS-316 & $1.5 \times 10^{-2}$ & $9.4 \times 10^{-3}$ & $7.2 \times 10^{-2}$ & $4.1 \times 10^{-1}$ & $6.6 \times 10^{-2}$ & \\
\hline $\mathrm{Nb}$ & $3.4 \times 10^{-3}$ & $2.2 \times 10^{-3}$ & $1.4 \times 10^{-2}$ & $9.2 \times 10^{-2}$ & $8.5 \times 10^{-3}$ & \\
\hline $\mathrm{Cu}$ & $1.7 \times 10^{-2}$ & $1.0 \times 10^{-2}$ & $8.6 \times 10^{-2}$ & $4.3 \times 10^{-1}$ & $1.1 \times 10^{-1}$ & \\
\hline A1 & $6.7 \times 10^{-3}$ & $4.3 \times 10^{-3}$ & $2.9 \times 10^{-2}$ & $2.0 \times 10^{-1}$ & $2.0 \times 10^{-2}$ & . \\
\hline MORSE/ANISN RATIO & & & & & & \\
\hline $\begin{array}{l}\text { SS-316 } \\
\text { Nb } \\
\text { Cu } \\
\text { Al }\end{array}$ & $\begin{array}{l}4862 \\
5666 \\
4250 \\
4466\end{array}$ & $\begin{array}{l}126 \\
110 \\
100 \\
102\end{array}$ & $\begin{array}{l}36 \\
40 \\
41 \\
32\end{array}$ & $\begin{array}{r}94 \\
141 \\
100 \\
111\end{array}$ & $\begin{array}{l}15 \\
13 \\
27 \\
11\end{array}$ & \\
\hline
\end{tabular}

(a) Atom parts per million per year 
TABLE. V. HELIUM GAS PRODUCTION RATES AT VARIOUS LOCATIONS IN THE TOROIDAL FIELD COILS

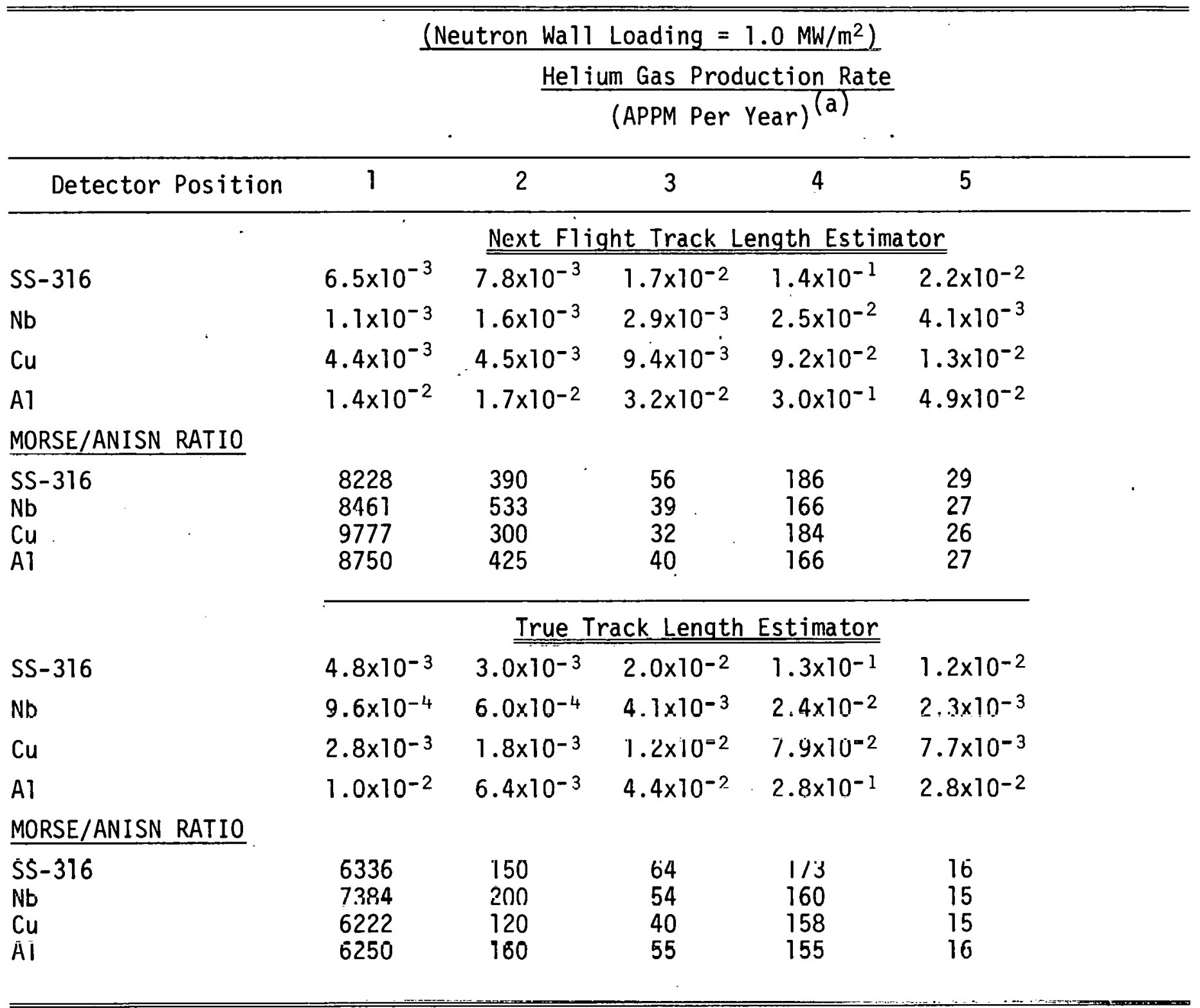

(a) Atom parts per million per year 
The increase in the radiation damage is largest at detector position 1 where, as noted above, the neutron streaming directly from the plasma is most severe. The large numbers of neutrons having energies greater than the threshold energies for the production of charged particles lead to the large values for the gas production rate relative to the fully shielded configuration. The influence of the injector duct on the radiation damage at detector position 2 is less than at detector location 1 because the neutrons are attenuated in passage through the blanket and shield material in the neutron path from the duct opening. The increases in the radiation damage at detector positions 3,4 , and 5 are comparable. The statistical uncertainties in the atomic displacement rates at detector position 3 are large and may be attributed to the difficulty in estimating the neutron distribution in a region of the TF coil where the secondary photon production dominates the total particle distribution.

The results given here are for a given reactor design and penetration size and orientation. Since the influence of penetrations on reactor performance depends on the geometry of both the penetration and the reactor, detailed calculations must be carried out to determine the magnitude of nuclear effects for specific reactor designs. 


\section{REFERENCES}

1. T. IDE, Y. SEKI, and H. IIDA, "Effects of Neutron Streaming Through Injection Ports on Neutronic Characteristics of A Fusion Reactor," Proc. of the Second Topical Meeting on the Technology of Controlled Nuclear Fusion, Vol. II; p. 395, Sept. 21-23, 1975, Richland, WA.

2. M. A. ABdOU, L. J. Milton, J. C. JUNG and E. M. Gelbard, "Multịdimensional Neutronic Analysis of Major Penetrations in Tokamaks," Proc. of the Second Topical Meeting on the Technology of Controlled Nuclear Fusion, Vol. II., p. 845, Sept. 21-23, 1975, Richland, WA.

3. M. B. EMMETT, "The MORSE Monte Cario Radiation Transport Code System," ORNL 4972, Oak Ridge National Laboratory, Oak Ridge, Tennessee (1975).

4. M. ROBERTS and E. S. BETTIS, "Oak Ridge Tokamak Experimenta Power Keactor Study Reference Uesign," URNL/TM-5042, Uak Ridge National Laboratory, Oak Ridge, Tennessee (1975).

5. R. T. SANTORO, V. C. BAKER, and J. M. BARNES, "Neutronics and Photonics Calculations for the Tokamak Experimental Power Reactor," ORNL/TM-5466, Oak Ridge National Laboratory, Oak Ridge, Tennessee (19்77).

6. W. W. ENGLE, JR., "A User's Manual for ANISN, A Onie-Dilinérisiumál Discrete Ordinates Code with Anisotropic Scattering," Report K1693, Computing Technology Center, Union Carbide Corporation, (1967) 
7. G. L. KULCINSKI et ar., "A Method to Reduce the Effects of Plasma Contamination and First-Wall Erosion in Fusion Reactors," UWFDM-108, University of Wisconsin (1974).

8. G. E. HANSEN and H. A. SANDMEIER, "Neutron Penetration Factors Obtained by Using Adjoint Transport Calculations," Nucl. Sci. Eng. 22, 315 (1965).

9. D. M. PLASTER, R. T. SANTORO, and W. E. FORD, III, "Coupled 100-Group Neutron and 21-Group Gamma-Ray Cross Sections for EPR Calculations," ORNL/TM-4872, Oak Ridge National Laboratory, Oak Ridge, Tennessee (1975).

10. W. E. FORD, III, R. T. SANTORO, R. W. ROUSSIN, and D. M. PLASTER, "Modification Number One to the Coupled 100n-21y Cross-Section Library for EPR Calculations," ORNL/TM-5249, Oak Ridge National Laboratory, Oak Ridge, Tennessee (1976).

11. M. A. ABDOU, C. W. MAYNARD, R. Q. WRIGHT, "MACK - A Computer Program to Calculate Neutron Energy Relase Parameters (Fluence-toKerma Factors) and Multigroups Neutron Reaction Cross Sections from Nuclear Data in ENDF Format," ORNL/TM-3994, Oak Ridge National Laboratory, Uak Ridge, Tennessee (1973).

12. N. M. GREENE et al., "AMPX: A Modular Code System for Generating Coupled Multigroup Neutron-Gamma Libraries froin ENDF/B," ORNL/TM-3706, Oak Ridge National Laboratory, Oak Ridge, Tennessee (1976).

13. T. A. GABRIEL, J. D. AMBURGEY, and N. M. GREENE, "Radiation-Damage Calculations: Primary Knock-On Atom Spectra, Displacement Rates, and Gas Production Rates," Nucl. Sci. Eng. 61, 21 (1976). 


\section{THIS PAGE}

WAS INTENTIONALLY

LEFT BLANK 
Internal Distribution

ORNL/TM-5874

1. L. S. Abbott

2. F. S. Alsmiller

3-4. R. G. Alsmiller, Jr.

5-6. J. M. Barnes

7. J. Barish

8. E. S. Bettis

9. J. F. Clarke

10. A. P. Fraas

11. T. A. Gabriel

12. F. Hammerling

13. G. Krist

14. R. A. Lillie

15. F. C. Maienschein

16. 0. B. Morgan, Jr.

17. F. R. Mynatt

18. E. M. Oblow

19. M. Roberts

20. M. W. Rosenthal

21. R. W. Roussin

22. RSIC

23-37. R. T. Santoro
38. J. L. Scott

39. D. Steiner

40-41. J. S. Tang

42. M. L. Tobias

43. N. A. Uckan

44. J. S. Watson

45. C. R. Weisbin

46. G. E. Whitesides

47. A. Zucker

48. P. F. Fox (consultant)

49. W. W. Havens, Jr. (consultant)

50. A. F. Henry (consultant)

51. R. E. Uhrig (consultant)

52-53. Central Research Library

54. ORNL Y-12 Technical Library Document Reference Section

55. Laboratory Records Department

56. Laboratory Records ORNL RC

57. ORNL Patent Office

\section{External Distribution}

58. H. Goldstein, Columbia University, 287A Mudd Building, New York, NY 10027.

59-85. Technical Information Center (TIC).

86. U.S. ERDA Oak Ridge Operations, Research and Technical Support Division, P.0. Box E, Oak Ridge, TN 37830: Director.

87-132. Given NPD-CTR External Distribution. 